\title{
Introduction
}

Parables are among the most dynamic, yet routinely neglected, literary forms in the corpus of Middle English texts. Despite their ubiquity in late medieval literature and the many essays that discuss a related history of biblical interpretation, the poetics and particularities of these vernacular narratives remain largely unexplored. Because of their scriptural roots, retold parables are often approached as static texts, stories with narrative arcs already familiar to many readers, whose meanings derive from their biblical 'original' and the scholarly exegesis of preceding generations. ${ }^{1}$ Instead of asking how a retelling makes meaning in its specific vernacular context, most studies ask what the biblical parable meant to other writers, especially those who wrote in Latin. In doing so, they imply that a narrative's meanings are constant, despite its different formulations, and easily transferable among varied times and settings.

This book argues that in the later Middle Ages, parables were lively, unstable narratives undergoing continual reinvention by writers eager to discern, or declare, their significance to contemporary English culture. As such, it advocates a mode of reading parables that seeks out and explores the implications of difference. Instead of assuming that writers imported authoritative doctrines into their larger works by means of translated parables, it asks what theological and social questions individual Gospel parables provoked, with what ongoing debates they intersected, and, in relation to these two factors, what claims translators made in their reconfiguration of the stories.

Simultaneously ordinary and enigmatic stories, grounded in the world but purporting to reveal divine truths, Gospel parables combine poetics, politics, and theology in disruptive and fertile ways that generated both interpretive debates and the construction of new stories. Those stories emerged not from a linear tradition 
of patristic, monastic, and scholastic exegesis but from a far more complex nexus of parable retellings and exegesis, known in Latin, French, and English, from written and oral sources, composed for diverse secular and spiritual purposes. Given this rhizomatic network of texts, ${ }^{2}$ discussion of past and contemporary exegesis valuably illuminates the conversations in which a parable retelling participates, but such exegesis - no matter how prominent - does not provide an interpretive key to any other version of a given parable. In our collective reliance on Latin exegetical texts, as well as our deference to scholastic theories of scriptural interpretation, we have overlooked a dynamic vernacular discourse about the nature of God, the coherence of scripture, and the forms of living consistent with Christian faith. This book uncovers and examines that discourse, demonstrating that Middle English parables are distinct poetic creations that diversely reconfigured not only sacred stories but also Christian belief and practice.

For an instructive example of our tendency to read past Middle English parables, we can briefly turn to a very short narrative in Piers Plowman - one that garnered considerable attention in a recent discussion of Langland's poetics. In passus 11 of the $\mathrm{B}$ text (and 12 of C), Langland rewrites what most editors identify as the Wedding Feast parable from Matthew's Gospel (22:1-14). ${ }^{3}$ His rendition consists of only three lines that the character Scripture narrates to the Dreamer: 'Multi to a mangerie and to be mete were sompned, / And whan pe peple was plener comen pe porter vnpynned be yate / And plukked in Pauci pryueliche and leet be remenaunt go rome' (11.112-14). 'The figures Multi (many) and Pauci (few) recall the Vulgate text of Matthew 22:14, where Jesus concludes the Wedding Feast parable with an aphorism: many are called, but few are chosen. ${ }^{5}$ Yet what happens to Multi and Pauci in this succinct story differs considerably from Matthew's parable. The Gospel story opens with a comparison of the kingdom of heaven to a king who organised a wedding for his son. When the king sends his servants to gather guests, they repeatedly refuse to attend, and some potential guests kill the servants. In an act of vengeance, the king destroys the murderers and their cities. He then orders more servants to bring everyone they can find to the wedding. When the tables are full, the king apprehends one man who came without a wedding garment and expels him to outer darkness where there is weeping and gnashing of teeth.

Langland's story lacks most of these narrative details, with no mention of rejected invitations or of violence from host or guests. 
Even more significantly, key features of the retelling do not appear in the Gospel story. Matthew's parable mentions neither a porter nor a gate for him to unpin, and in the Gospel version, only one is left outside the feast, not the many implied by 'be remenaunt [rest]' left to roam. Despite the obvious discordance between Matthew's narrative of a single expulsion and Langland's story of collective exclusion, scholars tend to equate Langland's story with Matthew's. In Piers Plowman: An Introduction, James Simpson writes that 'the parable Scripture chooses as her text (Matt. 22.1-14) is one that stresses both the openness of God's invitation, and the austerity of His judgment'. After briefly summarising the Gospel parable, Simpson describes and even quotes the Wedding Feast retelling in the late fourteenth-century poem Cleanness. ${ }^{6}$ Without analysing Langland's brief narrative, he interprets the scene in passus 11 in light of the Gospel story and the interpretation provided in another poem, as if Matthew's parable, the Cleanness rendition, and Langland's story of Multi and Pauci all relay the same narrative and project the same meanings.

The Multi and Pauci story receives sparse attention in Piers Plowman criticism, overshadowed as it is by the controversial Trajan episode that follows. ${ }^{7}$ The only extensive discussion of the passage I have found teaches readers much about earlier exegesis but engages very little with Langland's actual narrative. After identifying the Multi and Pauci tale as a reference to Matthew's parable, Thomas Ryan asserts that its (singular) theme 'is diametrically opposed to the Dreamer's superstitious faith in his baptism'. ${ }^{8}$ To show how the parable answers the Dreamer's misconception about the sufficiency of baptism for salvation, he cites Hugh of St Cher's commentary on the wedding garment - what the expelled guest lacks in Matthew's parable - that associates it with works and faith; he also cites Augustine's interpretation of the garment as faith with love. Ryan's reading, grounded in patristic and medieval exegesis, then compellingly links the concept of Lewte (loyalty or faith) that features so prominently in the Trajan episode with Augustine's commentary on the wedding garment. One nagging problem with this alluringly thematic reading is that Langland's story has no wedding garment. The reading depends upon a standard rendition and interpretation of a Gospel parable that Langland aggressively rewrites. As is so common in analyses of Middle English parables, the Gospel story and its history of exegesis receive critical attention, and the retold story - itself a creative and provocative comment on scripture - goes unexamined. ${ }^{9}$ 
Some might argue that in readings like Ryan's, we simply see the remnants of Robertsonian exegetical criticism, a mode of engagement with medieval literature that we have moved beyond as a field. And indeed, that claim is largely true: the article extends an interpretation from Robertson and Huppé, ${ }^{10}$ as it employs allegorical modes of reading that are now primarily relegated to the study of explicitly biblical texts. ${ }^{11}$ If, however, we find this mode of reading out-of-sync with the wider study of Middle English poetics, how might we read B.11.12-14 without deferring to the surrounding tradition of allegorical exegesis? One alternative approach emerged when the parable became the subject of stimulating discussion at the 2015 meeting of the International Piers Plowman Society. In a roundtable on 'Langland's poetics', speakers had been given a number of optional passages to discuss, but most were drawn to the provocative parable. With generative analysis of its syntax, lexis, alliteration, and imagery, the speakers illuminated the complexity of Langland's verse and its integrity to the substance of his narrative. ${ }^{12}$ Yet despite their close engagement with the tale, none of the speakers noted in their initial remarks how severely it differs from the biblical Wedding Feast, nor did they characterise the reimagining of that narrative as an aspect of Langland's poetics. ${ }^{13}$ In contrast with those who regard the story as equivalent to Matthew's Wedding Feast, this group moved away from biblical interpretation entirely, approaching Langland's Multi and Pauci story as a new narrative that effectively displaces the Gospel parable to which it alludes. ${ }^{14}$

This book advocates a mode of reading between these two poles, arguing that writers neither wholly imported nor displaced Gospel narratives when they retold parables. Rather, they engaged in a dynamic interpretive dialogue about the substance and meaning of a sacred story. In the case of Multi and Pauci, Langland's inscription of difference prompts audiences to consider a lack of logic in Matthew's Gospel. As Chapter 5 will demonstrate in far more detail, the Wedding Feast parable contains a number of jarring, even frightening, contradictions. And within passus 11, Langland highlights how unsuited the Gospel parable's famous aphorism is for the tale that precedes it. Matthew's parable makes clear that guests gained entry to the banquet, since it describes the feast as 'fulfillid with men sittynge at the mete' (22:10). ${ }^{15}$ Seemingly, the many were called and settle in for a festive meal, while only one suffers exclusion. Langland, in contrast, crafts a narrative that better corresponds to Matthew's conclusion: Multi are called but 
never breach the king's gate; only Pauci, secretly plucked out of the crowd, is chosen for admission to the feast. By retelling the parable in this way, Langland draws attention to the lack of clarity about salvation in this part of Matthew's Gospel. Why, his retelling prompts us to ask, would a story featuring the welcome of many and the expulsion of one suggest that few are chosen? If scripture really holds that only a few are chosen for salvation, it should narrate a tale like that of Multi and Pauci. When Langland posits an alternative parable in the place where readers expect a more familiar biblical story, he characterises the Wedding Feast as both an unsettling and unsettled passage of scripture, one whose meanings remain unclear and need to be discerned through further acts of storytelling.

Because Langland wrote (and rewrote) such a singular poem, it may be tempting to regard his reconfiguration of the Wedding Feast as atypical, the imaginative work of an exceptionally creative and recursive poet. But in fact, his parable illustrates a phenomenon that occurs across a wide range of vernacular texts: as writers translated parables into Middle English, whether in poems, sermons, Gospel harmonies, or devotional treatises, they reconfigured and newly interpreted the narratives. Like Langland's larger poem, Middle English parables combine the social and the spiritual, the artistic and the political in varied attempts to reconcile the divine word with the lived experience of late medieval culture. Rather than seek to preserve the precise Gospel narratives in the Vulgate, ${ }^{16}$ writers not only reshaped the stories with accompanying commentary but often also adapted their plot, setting, style, and tone to convey the truths they discerned within these fictions. ${ }^{17}$ Engaging in the same acts of interpretatio we associate with translators of non-biblical stories, writers of parables in Middle English created 'an original version of the same subject matter', revivifying the tales for contemporary audiences and repurposing them for new rhetorical contexts. ${ }^{18}$

Indeed, comparative study of Middle English parables reveals a striking lack of consensus about their respective meanings, illustrating Jocelyn Wogan-Browne's claim that vernacular translation exposes 'the gaps in supposedly united communities by demonstrating the crucial nonunitary meaning of texts now opened up to diverse constituencies'. ${ }^{19}$ Such interpretive diversity emerges, in part, from acts of cultural translation - efforts to determine what a sacred story means for a specific group of people in a specific place and time. ${ }^{20}$ Moreover, embedded in these culturally specific 
translations we find variation that stems from tensions within the Gospel stories themselves (why would those who work least receive equal pay to those who worked most?) and with contemporary religious structures (why does the sacrament of penance require confession when the Prodigal Son receives forgiveness on the basis of contrition alone?). The divergent ways that writers navigate such tensions reveals contesting opinions about the central beliefs and practices of late medieval Christianity and exposes fault lines in arguments related to the virtue of poverty, the practice of charity, and the possibility of salvation.

If we return one final time to the Wedding Feast parable and widen the horizon of our analysis beyond Langland's retelling, we find the parable intersected with late medieval debates about whether salvation was possible for all or restricted to an elite few. Interpretations of the expulsion scene, therefore, may promote a particular salvation theology or downplay the story's relevance to salvation altogether. In the Wycliffite Sermon Cycle, a writer interprets the guest's expulsion as a figure for the separation of holy church from the church of the fiend at final judgement. According to this reading, the parable supports a doctrine of election that attributes salvation to grace and restricts it to a select group. ${ }^{21}$ Within a penitential treatise, however, another writer supports a strenuous works-based soteriology with reference to the parable. $^{22}$ Interpreting the wedding garment as charity, he warns that if it is imperfect or unreliable ('nat parfit ne verrey'), then an individual will be rebuked and delivered to the jailers, or fiends of hell, without delay. ${ }^{23}$ The Cleanness-poet, in contrast, insists that salvation must be more widely available than the parable's expulsion scene implies. Despite the often frightening tone of the larger poem, he asserts that 'fele arn to called [many are called]' but notably omits the claim that few are chosen. ${ }^{24}$ These varied accounts demonstrate that, far from conveying a stable teaching, Middle English renditions of the Wedding Feast illuminate the competing perspectives of late medieval salvation theologies.

The interpretive diversity characteristic of Middle English parables requires a new paradigm of reading in which we expect such stories to reveal the problems that excited late medieval Christians, not normative doctrine handed down by tradition. In other words, it requires us to read parables as socially and spiritually engaged poetry. Like all works of fiction, parables generate multiple meanings and perplexing ambiguities. But because these fictions are attributed to a divine speaker, the literary activities of interpreting 
and retelling such stories take on a fundamentally theological character that is at once intellectual and practical, with translators attempting to discern and express both the nature of God and the forms of living that would lead to salvation. In Middle English parables, we find a distillation of the complex social and religious landscape of late medieval England, a reflection of its varied ideologies, power structures, anxieties, and ambitions, not right belief or normative exegesis.

\section{Parabolic fiction}

Among the many stories employed in teaching and preaching in the Middle Ages, parables are especially vexing and, therefore, especially generative tales. Like all narratives, they are fundamentally incomplete, leaving their readers to navigate gaps in information and mull over questions raised implicitly but left unanswered. ${ }^{25}$ And like all instructional stories, their ethical implications depend upon the literary context in which they appear (the stories' relationships to accompanying morals or their functions within larger texts) as well as their readers' subjective interpretations, informed by their particular experience of living. ${ }^{26}$ Indeed, parables have much in common with the moral exempla that populate medieval catechetical literature: at once general and particular, transhistorical and grounded in specific circumstance, exempla prompt the examination of moral principles even as they encourage actions that in some way imitate (or avoid) the models presented in the narratives. While parables may similarly prompt moral reflection and action, they have distinct formal qualities that set them apart from exempla as well. Although the narratives pertain to everyday life, their portrayals of that life frequently subvert readers' expectations. Moreover, parables are often explicitly metaphoric. As I will explain in more depth below, parables' strange rendering of events and figurative discourse foster reflection that is not only ethical but theological, leading audiences to wrestle with Christianity's most enigmatic and paradoxical teachings.

While modern biblical scholarship has produced a robust body of literature analysing the poetics and sociocultural dynamics of Gospel parables, ${ }^{27}$ medieval sources do not often engage in sustained discussions of their form, despite the fact that considerable ambiguity surrounded the genre. ${ }^{28}$ In the Middle Ages, the two most authoritative sources of information on parables offered competing characterisations. According to the classical rhetoric in 
which late medieval writers were well schooled, parables are a type of exemplum whose function was persuasive or pedagogical. ${ }^{29}$ Yet in the Gospels, the only theoretical statement about the genre characterises them as a means of concealing, not conveying, meaning. In Mark 4:11-12, after reciting the parable of the Sower, Jesus asserts that he speaks in parables to outsiders so that they might see, but not perceive, and hear, but not understand. Like many of the parables themselves, this characterisation is richly paradoxical, describing speech-acts that should obstruct communication and obscure meaning, at least for select groups. Since Jesus goes on to interpret the parable of the Sower allegorically (Mark 4:15-20), some medieval exegetes regarded parables as allegorical, pedagogical narratives whose figurative meanings would be misunderstood by outsiders. ${ }^{30}$ Yet even this conception of parables was problematic on two fronts. First, an allegorical model of storytelling is far too narrow to encompass all of the Gospels' references to and instances of parables. While this study focuses on narrative, in Christian scriptures, the Greek term parabole refers to a wider range of poetic speech, including comparison, symbol, proverb, riddle, and rule. ${ }^{31}$ Second, even when we narrow our focus to Jesus' stories, some defy the idea that parables, in the words of Andrew of St Victor, work toward 'the concealment rather than the manifestation of truth'. ${ }^{32}$ For example, both the parables of the Good Samaritan and of Dives and Lazarus resemble moral exempla that tell readers how to live. And Jesus narrates these stories, as well as the parable of the Great Supper, to sceptical opponents, seemingly with the expectation that they should comprehend his instruction. ${ }^{33}$ Such conflicting portrayals of the genre, both within scripture and between scripture and the classical tradition, cast parables as a potentially confusing but flexible literary form, one that writers would reinvent as they translated the stories into varied vernacular settings.

Even amidst this ambiguity, we can identify three common characteristics in Jesus' stories that likely influenced Middle English retellings. While such characteristics do not govern the structure or function of the translated stories, they can help us understand why Gospel parables generated so many divergent retellings. The primary point of consensus between modern and medieval accounts of parables is that they are fundamentally metaphoric. The word parable itself, coming from the Hebrew term mashal via the Septuagint's parabole, denotes likeness or similitude. ${ }^{34}$ That this definition persisted throughout the Middle Ages is evident 
from John Wyclif's description of parables in De veritate sacrae scripturae: ${ }^{35}$

Furthermore, concerning the matter of parables, one should consider that according to Januensis, 'Parables are called proverbs insofar as even images of the truth are demonstrated within them under the comparative similitude belonging to the figure of the words.' Hence he describes a parable as a comparison of things which belong to different genera. And according to Hugh [of St Victor], the word derives from para i.e., 'beside', and bola, i.e., 'meaning': 'a meaning which is placed beside', as it were. For it is not the meaning itself which indicates, but the meaning insofar as it set beside another. This agrees with Augustine, as he comments on Ps. 68 (69:12): I became a parable for them, 'it is called a parable when similitude is granted of something'. ${ }^{36}$

The equation of parable with similitude best fits those stories from Matthew's Gospel commonly known as 'parables of the kingdom', stories that Jesus introduces with a direct comparison: the kingdom of heaven is like a man who sowed good seed, like a grain of mustard seed, like a merchant in search of fine pearls, like a vineyard owner who went out to hire workers. Even these explicit comparisons, however, generated varied interpretations of both the kingdom of heaven and the person, object, or action said to signify it. And many Gospel parables, including four of the six discussed in this study, are narrated without an overt signal that they should be read metaphorically. The parables of the Good Samaritan and of Dives and Lazarus, we recall, both resemble exempla in their basic storylines; while the Samaritan parable was extensively allegorised across the Middle Ages, Dives and Lazarus mostly received historical and moral interpretations.

Although later medieval exegetes commonly characterised parables as a form of figurative speech, they included such narratives in scripture's literal sense, because their meanings were said to derive from the signification of words rather than the signification of things. ${ }^{37}$ The inclusion of parables among the literal sense of scripture did not, of course, contradict their classification as similitude or limit their meaning to a basic narrative. As Aquinas clarifies with regard to the genre, 'the literal sense is not the figure of speech itself, but the object it figures'. ${ }^{38}$ Instead, the classification of parables as literal discourse signals that they were regarded as both poetic - the literary product of human authors - and theological. ${ }^{39}$ Much like secular fables, parables evoked meanings far beyond their basic narratives and could teach audiences how to live. Yet 
these scriptural fictions employed such figurative language to explore the nature of God and human salvation. ${ }^{40}$

Modern analyses of Gospel parables continue to emphasise their metaphoricity, despite the emphatic rejection of medieval allegorical interpretation in twentieth-century exegesis. Working from a simplistic notion of allegory, modern scholars often clarify that parables do not signify something other than their basic narrative. Instead, as metaphor, they signify more. According to Robert Funk, because parables are metaphors, they cannot be reduced to their historical narratives or limited to one basic meaning. A parable 'intends more, much more than it says', conveying as much meaning as possible from minimal text. ${ }^{41}$ The author of the Northern Homily Cycle makes a similar assertion when introducing the Prodigal Son story, differentiating between Jesus' plain speech and his parables, through which he spoke 'mistily / And mened mekil more parby'. ${ }^{42}$ Whereas medieval exegetes would commonly identify multiple layers of meaning in a single image or phrase, modern readers more often attribute parables' expansive meaning to the interplay of text and context, what Paul Ricoeur calls the 'world of the text' coming into contact with a real world that differs according to time and place. ${ }^{43}$ Thus, as Funk asserts, parables take on new meaning as they are 'refracted in the changing light of the historical situation'. ${ }^{44}$ Whereas existing scholarship on Middle English parables often presents allegorical readings as if they transcend historical context, the chapters of this book pay special attention to how historical contexts engender new levels of meaning and reshape traditional allegories.

While medieval exegetes especially emphasised metaphor, they sometimes addressed a second prominent characteristic of the genre: engagement with everyday life. Parables feature familiar, sometimes banal worldly scenarios: a son moving away from a father's house, travel between two cities, the routines of planting and harvest, or hospitality at a feast. In scholastic discussions of the genre, this occupation with everyday life crucially separated parable from fable and the accompanying charge of falsehood that some levied at such explicitly fictional forms. In his thirteenthcentury guide to preaching, Thomas of Chobham articulates a Ciceronian schema differentiating three types of narrative: fable, realistic fiction, and history. ${ }^{45}$ Unlike fantastical fables with talking animals, parables belong to realistic fiction, or argumentum, that 'recounts events which might have taken place, even though they did not'. ${ }^{46}$ It is with such a schema in mind that we should interpret 
Wyclif's distinction between fanciful, unrealistic fables (like the talking trees of Judg 9) and the events of the Prodigal Son story that he describes as 'sufficiently possible'. Rather than showing a hesitance 'to admit that spiritual truths can be communicated by means of "fictions", as Kantik Ghosh has suggested, ${ }^{47}$ Wyclif's comments participate in a larger scholastic discourse identifying a unique dynamic of parables - that they communicate expansive figurative meanings via historically believable narratives. ${ }^{48}$

Although scholastic exegetes did not frame parables' historical relevance as an interpretive problem, writers of Middle English parables certainly grappled with the social and cultural implications of these worldly stories. When reading Gospel parables in light of their first-century sociopolitical context, modern scholars note that the narratives presented everyday life in provocative, even subversive ways. William Herzog, for example, describes parables as 'social analysis' that highlights injustice and transgression of norms. In doing so, he claims, Gospel parables 'explored how human beings could respond to break the spiral of violence and cycle of poverty created by exploitation and oppression'. ${ }^{49}$ Charles Hedrick agrees that a certain subset of Gospel parables highlight injustice; ${ }^{50}$ however, he describes the subversive potential of parables more broadly as a 'clash of fictions' between normative narratives that construct and affirm cultural practices and counternarratives that present an alternatively composed world. ${ }^{51}$ In this study, Middle English retellings of the Labourers in the Vineyard clearly display such a clash of fictions: some translators adapted the story to affirm contemporary socio-economic structures while others heightened disjunction between late medieval employment practices and those in the metaphorical vineyard. Similarly, in retelling the story of Dives and Lazarus (a narrative in which a rich man suffers damnation), some writers sought inventive ways to reduce conflicts between the Gospel story and contemporary modes of living, crafting narratives that assured wealthy readers they could live comfortably and devoutly.

The application of these realistic stories to actual medieval forms of living was troubled by a third characteristic of Gospel parables: their tendency to render the familiar unfamiliar. While this quality resists succinct, uniform description, modern scholars have long recognised that parables pull audiences into an interpretive puzzle. C. H. Dodd, a foundational figure in twentieth-century parable scholarship, indicates as much in his basic definition: 'at its simplest the parable is a metaphor or simile drawn from nature 
or common life, arresting the hearer by its vividness or strangeness, and leaving the mind in sufficient doubt about its precise application to tease it into active thought'. ${ }^{52}$ Gospel parables, he suggests, unsettle audiences and thereby usher them into active interpretation. More recent exegetes often explain parables' tendency to render the familiar unfamiliar in structural terms. Funk attributes to the stories a mysterious riddling or puzzle-like quality, comparing their dynamics to 'Alice's looking glass, through which one peers upon a strangely familiar world, where strangeness is suggested by the dislocation or rearrangement of the familiar'. ${ }^{53}$ Rather than straightforwardly affirming or condemning modes of living, for Funk, parables refract life in disorienting ways. The most extensive studies of how parables render the familiar unfamiliar come from John Dominic Crossan, who argues that Gospel parables are fundamentally paradoxical. At a basic level, paradox appears in the form of maxims like 'the last shall be first' or plot reversals like the exclusion of the long-sought wedding guest. But according to Crossan, the paradoxicality of parables goes beyond just one central inversion: he asserts that their 'entire pragmatics, semantics, and syntactics' are paradoxical and relates this to what he describes as the paradoxicality of Jesus' teaching, which 'both generates and undermines successive interpretations and applications just as it both generates and undermines moral imperatives, ecclesiastical structures, and political programs' ${ }^{54}$ While literary scholars often expect Middle English retellings to straightforwardly impart religious doctrine, modern studies of Gospel parables emphasise their tendency to build conflict and ambiguity, and in so doing to prompt audiences to confront the often uncomfortable, inscrutable distance between the human and the divine.

As Crossan argues, parables present an especially distilled form of the defamiliarisation and paradoxicality characteristic of Christian scriptures and dogma more broadly. Although medieval commentators do not describe parables as fundamentally strange, the first and last chapters of this study will feature a Middle English writer whose translated parables explore how Christian scriptures defy or exceed human logic: the author of Pearl and Cleanness integrates long retellings of parables into each poem, with renditions that make each story both more historically believable and more fraught with tensions than the versions in the Gospels. Those parables, the chapters will show, point beyond the discrete stories to encourage reflection on central Christian mysteries. While 
the Pearl-poet foregrounds paradoxicality, most writers featured in this study wrestle with translating narrative ambiguities and contradictions into embodied forms of living or worldly structures thought to manifest a divine order. Consequently, we will often observe writers softening points of tension within the Gospel stories, attempting to mould provocative, potentially disruptive parables into the persuasive teaching tools that classical rhetoric described parables to be.

The degree to which writers reduce narrative tensions often correlates with the generic aims and conventions of the larger works in which they retold parables, suggesting that the retold stories' characteristics and purposes largely depended upon their surrounding context. If Gospel parables are typically metaphoric, worldly, and strange, Middle English retellings may manifest one or all of these dynamics. They almost always remain grounded in everyday life, with writers often altering small elements of the stories to resonate with their present culture. While many are explicitly allegorical stories, some writers promote only moral interpretations based on their basic narratives. And while some writers create subversive stories, many ameliorate the provocative strangeness of the Gospel parables, translating them into narratives that affirm medieval social, economic, and religious systems.

The surviving corpus of Middle English parables makes clear that not only the meanings of particular stories but also the perceived function of Gospel parables remained unsettled throughout the later Middle Ages. While medieval writers had many ideas of what parables could do, there was no single defining idea of what parables should do. Although we might expect a given parable's scriptural context to clarify the function of each particular story, parables often travelled independently of the Gospel text: most prominently, when parishioners heard such stories within the liturgy, they often heard only a narrative without a framing conversation. ${ }^{55}$ In addition to their respective liturgical settings, the stories featured in this book are subsumed into larger narratives, paired with stories from other biblical books, interpolated with exegesis, presented as illustrations of vice, and cited as models of true penance or charity. Even if the stories themselves were pedantically straightforward, multiplicity of meaning would still emerge from the recreation of those stories within such varied settings.

This book, consequently, will not only uncover cultural and theological debates manifest in parable translations but will also outline a series of competing assumptions about the parable genre. 
The chapters that follow contribute to the study of what Nicolette Zeeman has called 'imaginative literary theory', insofar as they investigate late medieval understandings of parables through renditions of the stories themselves. ${ }^{56}$ Moreover, by calling attention to the interplay of narrative and the larger literary forms in which they appear, the chapters add credence to Ingrid Nelson and Shannon Gayk's claim that 'medieval genre is fundamentally recombinative' in ways that are both 'responsive to and generative of cultural practice'. ${ }^{57}$ In other words, the forms of retold parables are informed by a nexus of known renditions and by the larger texts (sermon, conduct book, devotional guide, etc.) in which they are inscribed, texts whose own structures encode cultural assumptions and ambitions that affect how parables make meaning.

\section{Translating parables in context}

The chapters that follow focus on the five most commonly retold parables in Middle English. With the exception of the Prodigal Son story, each appears in a well-known literary work as well as in a range of more pragmatic genres. Rather than attempt to survey all Middle English retellings of a given story, chapters will juxtapose the retelling from a widely read poem with renditions of the parable in one or a small number of select genres. In this way, the study as a whole explores a wide variety of settings in which writers reinvented parables and their functions, while still offering sustained analysis of select texts.

The first chapter brings together the rendition of the Labourers in the Vineyard parable from Pearl - a poem that is both deeply theological and ornately aesthetic - with renderings and explications of the same story in Middle English sermons. The pairing is apt both because scholars have described the Pearl-maiden's narration as a homiletic speech and because renditions in the two genres so sharply contrast one another. In sermons, preachers translated parables into a discourse that aimed to teach audiences how to live. As Alan Fletcher describes, in their efforts to demonstrate the applicability of scriptural stories to contemporary life, preachers attempted 'to settle popular audiences in a position from which they could recognize with unobstructed view how the landscape of their lives was in fact a morally charged landscape' ${ }^{58}$ Preachers' explications, in other words, assigned spiritual values to sociopolitical structures and events. In sermons on the Labourers in the Vineyard, writers integrated scripture with contemporary 
life by claiming that the events of the parable endorsed traditional social hierarchies and post-plague labour practices. These conservative readings of a potentially disruptive parable may derive not only from sermons' broad tendency to foster social stability but also from the specific liturgical occasion on which the parable would be read. According to the Sarum Rite, Matthew 20:1-14 was read on Septuagesima Sunday, a celebration that marked seventy days before Easter and that ushered in the season of Lent. On this liturgical occasion preachers sought to foster diligent piety and penitential acts; John Mirk, for example, admonishes his audience to more busily, meekly, and devoutly serve God. ${ }^{59}$ Yet these ecclesiastical priorities could be undermined by a Gospel text that celebrates and rewards those who worked the least. The chapter argues that the particular emphases of Septuagesima, together with the general sociopolitical function of sermons, inspired retellings that more clearly promoted labour as a form of obedience to God. And it portrays the Pearl-maiden's speech as a counter-discourse arguing against the widespread tendency to equate the contemporary material economy with salvation economy.

The second chapter features retellings of the Prodigal Son parable in a wider array of genres that teach right living and devotion. Like the Labourers in the Vineyard, this story could call into question the necessity of spiritual work: much to his brother's chagrin, the prodigal son receives an honoured welcome when he returns home after wasting his inheritance in a life of sin. More poignantly, however, the narrative could clash with doctrines surrounding sacramental penance, since the son seems to be forgiven before confessing or doing acts of satisfaction. Because the parable does not appear in any major works of Middle English poetry (not even Gower's quasi-penitential collection of tales), the chapter highlights a retelling in the late medieval 'form of living' known as Book to a Mother - a work that has received increasing attention in recent scholarship on vernacular theology and Lollardy. Like many vernacular sermons, Book to a Mother presents basic elements of the faith, translations of scripture, and explications applying those texts to daily life, but it does so while outlining an ambitious programme for pursuing spiritual perfection. Because its author claims that the book fulfils the aims of three genres - mirror, remedy, and rule - the chapter explores retellings in three corresponding categories of texts: lives of Christ, sermons, and forms of living. In doing so, it demonstrates that the degree to which writers integrate a threefold process of penance (including contrition, confession, 
and satisfaction) into the Prodigal Son narrative correlates with the respective genres' conventions. Texts devoted to showing who God is show the least concern about the son's particular actions before he reconciles with his father, while sermons more commonly emphasise and even revise the son's act of confession. Book to a Mother, a form of living or rule, stands alone in its integration of a complete threefold process of penance into the parable. What complicates this seemingly straightforward schema is Book to a Mother's ideological affiliations: this potentially Lollard work that critiques the clergy and encourages lay people to teach the Gospel contains the most 'orthodox' depiction of sacramental penance. Therefore, the chapter's examination of how writers reconciled the parable with penitential doctrine prompts us to reconsider common assumptions about the sacrament's power dynamics and reveals a discourse in which penance empowers the individual subject rather than priests.

The subject of penance remains prominent in the third chapter, where I examine translations of Dives and Lazarus within confessional and conduct treatises that teach readers about the seven deadly sins. Like Book to a Mother, such treatises can be catechetical in nature: Robert Mannyng's Handlyng Synne, the earliest of the three works featured in the chapter, includes instruction in the ten commandments as well as the seven deadly sins and is often cited as a text that brings elements of Pecham's syllabus into Middle English. Yet the chapter also features retellings in John Gower's Confessio Amantis, which playfully applies the form of the confessional treatise to the secular problem of unrequited love, as well as in Peter Idley's Instructions to His Son, which pairs penitential instruction with pragmatic conduct advice for a fifteenth-century gentleman. The three writers use the confessional framework to differing ends, but they nonetheless share a literary form that sets up a common interpretive question: what does the parable of Dives and Lazarus teach readers about the sin of gluttony?

The chapter both examines how the parable and moral framework mutually influence one another and inquires into the implications of not sorting the story under the more predictable category of greed. In Dives and Lazarus, a rich man refuses to share food with the poor, sick man at his gate. And after death, he can see that same man resting in the bosom of Abraham while he suffers in Hell. Both the Gospel and the Glossa ordinaria associate the story with avarice. ${ }^{60}$ Middle English works consistently sort the story under the sin of consuming rich foods (the branch of gluttony known as 
delicacy), potentially making the story less jarring for the writers' wealthy audiences. Yet at the same time, by discussing greed obliquely, they make varied claims about the social implications of gluttony and prompt readers to reconsider the public dimensions of an interior process - examination of conscience.

Building on these discussions of Christian community, Chapter 4 examines the ethical imperatives associated with the Good Samaritan parable, especially as expressed in lives of Christ and Piers Plowman. Vitae Christi texts present the Gospels in a single narrative, rendering the different events and speeches in the four Gospels more coherent and thereby more imitable, so that Christ's life may serve as the ultimate exemplar for charitable living. This genre's exemplary mode pairs well with the Samaritan parable in Luke's Gospel, where Jesus concludes his story by telling his audience to go and do likewise. Yet in the Middle Ages, that injunction to imitation had been complicated by a long tradition of christological interpretation. The Samaritan, according to such allegories, represented Christ, while ordinary Christians should see themselves in the figure of the wounded man whom Christ heals. The chapter uncovers two distinct but not unrelated tensions across Middle English retellings. The first pertains to moral interpretations that function at the basic level of the story. If audiences should behave like the Samaritan, what type and extent of charitable action did that injunction require? Writers sometimes came to sharply contrasting conclusions: according to the Pepysian Gospel Harmony, the parable urges audiences to love everyone, but the South English Ministry and Passion asserts that the story teaches Christians to act charitably toward those who love them in return. A second tension derives from the singularity of the Samaritan's actions. If they represent Christ's passion, how should one imitate the uniquely divine action of redemption effected in the crucifixion? Piers Plowman brings together both of these questions in his vita Christi narrative in B.17. Langland vividly animates a Christological allegory, merging the Samaritan with Jesus-theJouster, who heals a wounded man while en route to Jerusalem where he will be crucified. Yet rather than overshadowing the basic narrative and its moral injunction, Langland's allegorical retelling participates in late medieval debates about what it means to love your neighbour. While still enjoining indiscriminate charity, Langland rejects exemplarity as a reliable means of manifesting Christ's love and instead advocates participation with God through a variety of social actions befitting one's particular station. 
The fifth chapter returns to the parable of the Wedding Feast - a story that raises questions about the nature of God and the veracity of scripture, questions that the Pearl-poet brings to the fore while retelling the parable in the late fourteenth-century poem Cleanness. Like the poem, the larger chapter brings together the Wedding Feast parable from Matthew's Gospel with Luke's parable of the Great Supper (14:16-24), since the latter closely resembles the first half of the Wedding Feast story. It argues that reading the two stories together prompts audiences to reflect not only on their conduct (whether they are worthy guests) but also on the nature of God and the consistency of scriptural revelation. Despite their common plotlines featuring invitation, rejection of that invitation, and the summoning of new guests, the two stories present radically different host figures: the Wedding Feast host engages in acts of violence and unforgivingly expels a guest from his gathering, while the Great Supper host simply welcomes people from all walks of life, including the most marginalised. The chapter, therefore, asks how writers made sense of two similar parables suggesting that God is both gracious and severe, that the kingdom of heaven is both democratic and exclusive. Given the speculative, intellectual nature of this question, the chapter also highlights a Middle English version of a scholastic genre: the commentary collection. The Wycliffite Glossed Gospels, modelled on Aquinas's Catena aurea, present readers with a brief history of accumulated interpretation and, in doing so, they show that polysemic variety was a defining characteristic of medieval exegesis. Insofar as the glosses reveal discord within the interpretation of a single parable and between the two parables' interpretive traditions, they offer a model for understanding the Cleanness-poet's composition that so often foregrounds paradox. Although the poet harmonises disparate biblical passages, he maintains and sometimes sharpens the contradictions that emerge between the two parables and between the two testaments of scripture. By highlighting narrative disparity, I argue, he asserts that God transcends human understanding. Together with the diverse readings in the Glossed Gospels, such retellings of the Wedding Feast and Great Supper parables reveal a common willingness among Wycliffites and mainstream writers to embrace discord and ambiguity in the search for divine truth.

Collectively, the chapters demonstrate that the project of retelling parables was rife with contradictions - some integral to the basic Gospel narratives, some that appear between those narratives and prominent cultural practices, and others that emerge from dif- 
ferent writers' interpretations inscribed in their translations. The epilogue, therefore, argues that we can observe a parabolic mode in Middle English literature beyond retellings, when writers created perplexing, potentially counter-cultural narratives that generate a wide range of divergent interpretations or new narratives. A prime example of this mode is Piers Plowman's pardon episode. Langland constructs this narrative around a paradox - the notion that a works-based soteriology is itself a form of pardon - that sharply contradicts audience expectations. In doing so, he engages readers in the interpretation of a seemingly unreasonable but spiritually and socially formative tale that does not clarify doctrine but instead incites the search for truth.

\section{Notes}

1 I place original in quotation marks to remind readers that scripture is never static text untouched by writerly interventions. The canon of Judeo-Christian scriptures authoritative in the later Middle Ages was composed across centuries (often by transforming older oral traditions into written form), copied by innumerable scribes, translated from Hebrew to Greek and from Greek into Latin, arranged and divided in innovative ways, and interpreted and employed by readers in varying cultures and social positions. For an introduction to the gradual, collaborative composition of scripture, see Mark McEntire, Struggling with God (Macon, GA: Mercer University Press, 2008), pp. 11-23. On the material history of the Bible, including translation from Hebrew and Greek to Latin as well as innovations in textual arrangement, see Christopher de Hamel, The Book. A History of the Bible (London: Phaidon Press, 2001).

2 Eleanor Johnson describes a rhizomatic network as one in which 'complex, intersecting, and shallowly buried lines of relationality run among a set of related literary works. Each work is recognisably related to others in the system, and all can be linked to one progenitor, but the various branchings of the buried network make the direct ascription of exclusionary filiation or linear hierarchy both impossible and misleading. The patterns of growth within this rhizomatic literary tradition are gnarled and recursive, rather than clean and linear.' See Practicing Literary Theory in the Middle Ages (Chicago: University of Chicago Press, 2013), pp. 10-11, as well as Gilles Deleuze and Félix Guattari, 'Introduction: Rhizome', in Brian Massumi (trans.), A Thousand Plateaus: Capitalism and Schizophrenia (Minneapolis: University of Minnesota Press, 1987), pp. 3-25.

3 Most editors emphasise the aphorism in Matthew 22:14 but also refer readers to the fuller Wedding Feast story. For example, Skeat's parallel 
text edition states that 'the Vulgate version has: Multi enim sunt uocati, pauci uero electi; Mat. xxii. 1-13'. The most recent Norton Critical edition provides similar information, suggesting that the single line invokes the full parable: 'Multi (line 112): "many." Pauci: "few": Matt. 22:1-14; the Latin words occur in verse 14, "Many are called, but few are chosen." Pearsall's Middle English edition of the C text calls the three lines 'a summary of the parable of the marriage-feast, which in Matt. 22:14 concludes: "Many (multi) are called, but few (pauci) are chosen." See Walter W. Skeat (ed.), The Vision of William concerning Piers the Plowman in Three Parallel Texts, 2 vols (Oxford: Clarendon, 1886), 2:168; Elizabeth Robertson and Stephen H. A. Shepherd (eds), Piers Plowman (New York: Norton, 2006), p. 169; and Derek Pearsall (ed.), Piers Plowman the C-text (reprint, Exeter: University of Exeter Press, 2003), p. 212.

4 George Kane and E. Talbot Donaldson (eds), Piers Plowman: The $B$ Version, revised edition (London: Athlone Press, 1988). The same lines appear in C.12.47-9, with only one difference: 'plukked' in the B text appears as 'plihte' in the Athlone version of the $\mathrm{C}$ text.

5 'Multi enim sunt vocati pauci vero electi.' All quotations of the Vulgate come from Alberto Colunga and Laurentio Turrado (eds), Biblia Sacra iuxta Vulgata Clementinam, $5^{\text {th }}$ edition (Madrid: Biblioteca Autores Cristianos, 1977).

6 James Simpson, Piers Plowman: An Introduction, revised edition (Exeter: University of Exeter Press, 2007), pp. 107-8.

7 In his rich analysis of the Trajan episode, Joseph Wittig invokes the Mutli and Pauci passage multiple times in relation to the importance of works, but he does not explicitly mention the parable or analyse the specific lines. His references to the passage, therefore, imply that the particular verse of scripture or the parable should carry a self-evident meaning. See 'Piers Plowman B, Passus IX-XII: Elements in the Design of the Inward Journey', Traditio, 28 (1972), 242, 244, and 257.

8 Thomas Ryan, 'Scripture and the Prudent Ymaginatif', Viator, 23 (1992), 219. Although Ryan never directly articulates the singular theme to which he refers, his analysis ties the parable to a discourse about the necessity of works for salvation. In contrast, in his edition of the C text, Derek Pearsall associates Langland's rendition with salvation by election. In a highly interpretive note, he emphasises Langland's omission of the refused invitations from Matthew's story: 'the version presented here eliminates altogether the suggestion of the early part of the parable (22:3-6) that the wicked, in refusing the invitation, choose to show themselves unworthy; it stresses therefore the idea of pre-election to God's grace, and raises again (cf. XI 208), more acutely, the problem of predestination'. See Pearsall (ed.), Piers Plowman the C-text, p. 212.

9 The only book-length study of medieval parables, Stephen Wailes, 
Medieval Allegories of Fesus' Parables (Berkeley: University of California Press, 1987), facilitates this type of study. Since it catalogues interpretations extracted from their rhetorical contexts, it suggests that a parable can carry a set of meanings independent of its surrounding literary and cultural contexts.

10 With his integration of Augustine, Ryan gives a more nuanced version of Robertson and Huppé's claim that 'Augustine's sermon on the parable makes clear [the parable's] use in the poem ... Will must learn to wear the marriage robes of charity, of humility, and of faith.' D. W. Robertson and Bernard F. Huppé, Piers Plowman and Scriptural Tradition (Princeton, NJ: Princeton University Press, 1951), pp. 134-5.

11 For a positive account of Robertsonian criticism that attempts to locate afterlives of his work, see Alan T. Gaylord, 'Reflections on D. W. Robertson and Exegetical Criticism', Chaucer Review, 40:3 (2006), 311-33. For an ambitious effort to revitalise and redirect exegetical criticism, see Ryan McDermott, Tropologies: Ethics and Invention in England, c. 1350-1600 (Notre Dame, IN: University of Notre Dame Press, 2016).

12 One speaker, for example, analysed Langland's linguistic innovation as he deployed a cluster of new words, a second argued that Langland used an 'inclusive' poetics, incorporating Latin, French, and English vocabulary, to project an image of exclusivity, and a third noted how Langland extended a pattern of alliteration beyond a single line to unite the narrative's central events.

13 At least implicitly, speakers seemed to agree with D. Vance Smith, who intriguingly claimed that Langland often invokes texts in order to set them aside.

14 On the Ciceronian idea of translation as displacement, see Rita Copeland, Rhetoric, Hermeneutics, and Translation in the Middle Ages (Cambridge: Cambridge University Press, 1991), pp. 30-6.

15 Unless otherwise indicated, all biblical quotations come from J. Forshall and F. Madden (eds), The Holy Bible, Containing the Old and New Testaments, with the Apocryphal Books, in the Earliest English Versions, made from the Latin Vulgate by Fohn Wycliffe and his Followers, 4 vols (Oxford, 1850; reprint New York: AMS Press, 1982). I quote from the Wycliffite Bible, rather than the Vulgate or the Douay-Rheims translation, for a number of reasons - to highlight the varied forms of vernacular scripture produced in late medieval England, to increase our familiarity with this much-discussed but little-read translation, to avoid reifying the Vulgate as the authoritative form of scripture in the later Middle Ages, and to ensure that the Vulgate does not appear to be the source for retellings that respond to a variety of earlier texts, written and oral, known and unknown. On the Wycliffite Bible translations, see Mary Dove, The First English 
Bible: The Text and Context of the Wycliffite Versions (Cambridge: Cambridge University Press, 2007), pp. 137-88.

16 The assumption that serious translators should endeavour to preserve their source text pervades much of the scholarship on Middle English scripture, giving rise to an artificial division between 'translation' and 'adaptation' rarely invoked with reference to non-scriptural texts. Copeland traces the preservation-model of translation to Jerome and Augustine, who promoted close translation as a mode of continuity by which an original meaning could be transferred across languages and time without being obscured by or appropriated for the purposes of particular human cultures. That model contrasts with a classical disjunctive model that inscribes difference and reinvents a text in light of its exegetical history and its present context. See Copeland, Rhetoric, Hermeneutics, and Translation, pp. 44-5.

17 Later medieval exegetes commonly described parables as fictitious and truthful. Among others, Alastair Minnis quotes Ulrich of Strassburg's description of parables as 'truth under fictional garments'. See Medieval Theory of Authorship: Scholastic Literary Attitudes in the Later Middle Ages, 2nd edition (Philadelphia, PA: University of Pennsylvania Press, 2010), p. 140.

18 On interpretatio, see Douglas Kelly, 'The Fidus interpres: Aid or Impediment to Medieval Translation and Translatio?' in Jeanette Beer (ed.), Translation Theory and Practice in the Middle Ages (Kalamazoo, MI: the Medieval Institute, 1997), pp. 57-8.

19 Jocelyn Wogan-Browne et al. (eds), The Idea of the Vernacular (University Park, PA: Pennsylvania State University Press, 1999), p. 115.

20 As Lawrence Venuti has convincingly argued, cultural interventions occur even when translators aim to avoid them with a transparent rendering of their source texts. Translation, he writes, necessarily involves 'the reconstitution of the foreign text in accordance with values, beliefs and representations that preexist it in the target language, always configured in hierarchies of dominance and marginality, always determining the production, circulation, and reception of texts'. Venuti, The Translator's Invisibility: A History of Translation (New York: Routledge, 1995), p. 18.

21 Anne Hudson (ed.), English Wycliffite Sermons (Oxford: Clarendon Press, 1983), 1:303. On Wycliffite ecclesiology, see Anne Hudson, The Premature Reformation: Wycliffite Texts and Lollard History (Oxford: Clarendon Press, 1988), pp. 314-27. On the diversity of Wycliffite views about salvation and the importance writers place on human action, see Fiona Somerset, Feeling Like Saints: Lollard Writings After Wyclif (Ithaca, NY: Cornell University Press, 2014), pp. 30-1 and J. Patrick Hornbeck, What is a Lollard? Dissent and Belief in Late Medieval England (Oxford: Oxford University Press, 2010), pp. 25-67. 
22 The treatise appears in Cambridge, Magdalene College MS Pepys 2125. For an edition, see Mayumi Taguchi, 'A Middle English Penitential Treatise on Job 10:20-22, Dimitte me, Domine ... ', Mediaeval Studies, 67 (2005), 157-217.

23 Taguchi, 'A Middle English Penitential Treatise', 199.

24 Malcolm Andrew and Ronald Waldron (eds), 'Cleanness', in The Poems of the Pearl Manuscript, 4th edition (Exeter: University of Exeter Press, 2002), p. 162.

25 Patrick O'Neill, Fictions of Discourse: Reading Narrative Theory (Toronto: Toronto University Press, 1994), p. 19.

26 On the reception dynamics of exemplary narratives, see J. Allan Mitchell, Ethics and Exemplary Narrative in Chaucer and Gower (Cambridge: D.S. Brewer, 2004); Elizabeth Allen, False Fables and Exemplary Truth in Later Middle English Literature (New York: Palgrave Macmillan, 2005); and Catherine Sanok, Her Life Historical: Exemplarity and Female Saints' Lives in Late Medieval England (Philadelphia: University of Pennsylvania Press, 2007).

27 Twentieth-century parable scholarship credits Adolf Jülicher with initiating the study of parables' poetics, due to his firm rejection of medieval allegorical interpretation (which drew meaning from individual parts of the narrative) and his contention that the full narrative projected a metaphoric meaning. Other influential figures in the first half of the twentieth century include C. H. Dodd and Joachim Jeremiah, who both followed Jülicher in asserting that parables projected one primary meaning but tried to interpret them in light of their Sitz im Leben. Later scholars, as I will outline below, attributed to parables more expansive meanings.

28 In the later Middle Ages, brief statements about Gospel parables typically appear in discourses about the truth of scripture and articulations of its figurative modes (see pp. 9-10). On the tendency of medieval texts to discuss what a genre does, as opposed to defining what a genre is, see Ingrid Nelson and Shannon Gayk, 'Introduction: Genre as Form-of-Life', Exemplaria, 27:1 (2015), 5. With regard to instructional narrative specifically, see Larry Scanlon's assertion that 'medieval culture was keenly interested in using narrative, but it was less interested in discussing it'. Scanlon, Narrative, Authority, and Power: The Medieval Exemplum and the Chaucerian Tradition (Cambridge: Cambridge University Press, 1994), p. 27.

29 Stephen Wailes discusses Aristotelian and Ciceronian theories and concludes that 'this rhetorical tradition made all scholars in the period of our interest aware that the parabola or similitudo - terms that alternate in the Latin Bible as they do in related exegetical writings - was a figurative device to facilitate, not to impede, communication and persuasion. The parable's essence was clarity in the figurative demonstration of truth.' See 'Why Did Jesus Use Parables? The Medieval 
Discussion', Medievalia et Humanistica, 13 (1985), 49. For Aristotle's characterisation of parables as a type of example, see 'Rhetoric', in The Works of Aristotle, vol. 11: Rhetorica; De rhetorica ad Alexandrum; De poetica, trans. W. D. Ross (Oxford: Clarendon Press, 1924), $2: 20$.

30 On the citation of the Sower parable to justify allegorical reading, see Wailes, 'Why Did Jesus Use Parables?' 54.

31 On the use of the term parable in the Gospels, see Joachim Jeremias, The Parables of Fesus, revised edition (London: SCM Press, 1972), p. 20.

32 Frans van Liere (trans.), 'Andrew of Saint Victor: Prologues to Select Commentaries', in Franklin T. Harkins and Frans van Liere (eds), Interpretation of Scripture: Theory (Turhout: Brepols, 2012), pp. 280-1. According to Minnis, Nicholas of Trevet and Thomas Ringstead make similar claims that parables 'taught in an apparently fictional manner and through a sort of concealment'. Minnis, Medieval Theory of Authorship, p. 131.

33 Jesus narrates the Samaritan parable to a lawyer 'temptynge hym' (Luke 10:25), and he recites both the parables of Dives and Lazarus and the Great Supper to Pharisees. See Luke 16:14 and Luke 14:1, respectively.

34 On the meaning of mashal in midrashic texts, see Daniel Boyarin, 'Take the Bible, for Example: Midrash as Literary Theory', in Alexander Gelley (ed.), Unruly Examples: On the Rhetoric of Exemplarity (Stanford, CA: Stanford University Press, 1995), pp. 27-47.

35 Both the Vulgate and the Wycliffite Bible sometimes use the term similitude, rather than parable, to introduce a story. For example, in Matt 13 and Mark 4 in the Vulgate, the parable of the Sower is introduced as an example of Jesus speaking in parabolis, but the Vulgate version of Luke introduces the same story as Jesus speaking per similitudinem (8:4). In the early version of the Wycliffite Bible, the relevant term in Luke 8:4 is rendered 'liknesse' and often accompanied by the gloss 'or ensaumple'. The later version, however, returns to the Vulgate's term 'symylitude'.

36 John Wyclif, On the Truth of Holy Scripture, ed. Ian Levy (Kalamazoo, MI: Medieval Institute Publications, 2001), p. 78.

37 On the signification of things, or the distinction between spiritual senses and metaphor, see, Christopher Ocker, Biblical Poetics Before Humanism and Reformation (Cambridge: Cambridge University Press, 2002), pp. 34-7.

38 See Summa Theologiae 1a. 1.10. In the fourteenth century, some exegetes began to refer to a double literal sense of scripture, with the second level encompassing figurative speech. For William of Nottingham and Nicholas of Lyra on the duplex sensus litteralis, see A. J. Minnis and A. B. Scott (eds), Medieval Literary Theory and 
Criticism c.1100-c.1375, revised edition (Oxford: Oxford University Press, 1991), pp. 205-6.

39 Their classification as literal discourse belonged to a broader movement of recognising different literary modes within scripture and attributing greater intentionality to scripture's human authors. See, for example, the discussion and excerpts of Alexander's Sum of Theology in Minnis and Scott (eds), Medieval Literary Theory, especially pages 200-3 and 219. Also relevant is Ocker's discussion of whether late medieval exegetes considered the parabolic sense univocal, following Lyra, or polyvocal. See Biblical Poetics, pp. 142-9.

40 See Ocker, Biblical Poetics, pp. 21, 144-5.

41 Robert Funk, 'Parable as Metaphor', in Bernard Brandon Scott (ed.), Funk on Parables (Santa Rosa, CA: Polebridge Press, 2006), p. 35.

42 Saara Nevanlinna (ed.), The Northern Homily Cycle, vol. 2: From Septuagesima to the Fifth Sunday after Trinity, Mémoires de la Société Néophilologique de Helsinki 41 (Helsinki: Société Néophilologique, 1973), p. 54/7266-7.

43 Paul Ricoeur, From Text to Action, trans. Kathleen Blamey and John Thompson (Evanston, IL: Northwestern University Press, 1991), p. 6. Discussing medieval scriptural exegesis more broadly, Ocker has argued that commentators often tried to reconcile scripture with their particular historical moment, whether explicitly or as reflected in their 'unique theological interests'. See Biblical Poetics, pp. 52-65.

44 Funk, 'Parable as Metaphor', p. 36.

45 Rita Copeland and Ineke Sluiter call this threefold categorisation 'the oldest and most constant generic taxonomy in the Middle Ages'. On its Ciceronian roots and its common articulation in medieval texts, see Medieval Grammar and Rhetoric: Language Arts and Literary Theory, AD 300-1475 (Oxford: Oxford University Press, 2009), pp. 42-3.

46 Thomas of Chobham, 'Summa de arte praedicandi', in Copeland and Sluiter (eds), Medieval Grammar and Rhetoric, p. 617.

47 Kantik Ghosh, The Wycliffite Heresy: Authority and the Interpretation of Texts (Cambridge: Cambridge University Press, 2002), pp. 33-5.

48 Minnis notes that the English Carmelite John Baconthorpe also 'carefully distinguished between a fabula, which is a falsehood, and a parable, which is an example signifying truth'. See Medieval Theory of Authorship, p. 144.

49 William Herzog, Parables as Subversive Speech: Fesus as Pedagogue of the Oppressed (Louisville, KY: John Knox Press, 1994), p. 3. For another socio-historical reading of parables, see Luise Schottroff, The Parables of Fesus, trans. Linda M. Maloney (Minneapolis, MN: Fortress Press, 2006).

50 John Dominic Crossan similarly describes a group of Jesus' parables as 'challenge parables' but does not apply this description to all. See Charles Hedrick, Many Things in Parables: Fesus and His Modern 
Critics (Louisville: Westminster John Knox Press, 2004), pp. 75-6 and Crossan, The Power of Parable: How Fiction by Fesus Became Fiction about Fesus (New York: Harper Collins, 2012), p. 47.

51 Hedrick's assertion that all cultures define themselves by means of normative fictions is based on the writings of Frank Kermode. See Charles Hedrick, Parables as Poetic Fictions: The Creative Voice of Fesus (Peabody, MA: Hendrickson Publishers, 1994), pp. 73-89.

52 C. H. Dodd, The Parables of the Kingdom (New York: Scribner, 1961), p. 5.

53 Funk, 'Parable as Metaphor', p. 38.

54 John Dominic Crossan, Cliffs of Fall: Paradox and Polyvalence in the Parables of Fesus (New York: Seabury Press, 1980), pp. 19, 23.

55 For example, although the Parable of the Labourers in the Vineyard is narrated within an extended discourse that starts in Matthew 19, the reading for Septuagesima Sunday according to the Sarum Rite begins with the comparison to the kingdom of heaven in Matthew 20. Biblical cues about the story's meanings and rhetorical function are absent and effectively replaced by the context of other liturgical readings and the emphases of that occasion.

56 Nicolette Zeeman, 'Imaginative Theory', in Paul Strohm (ed.), Oxford Twenty-First Century Approaches to Literature: Middle English (Oxford: Oxford University Press, 2007), pp. 222-40.

57 Nelson and Gayk, 'Introduction', 8.

58 Alan Fletcher, Late-Medieval Popular Preaching in Britain and Ireland (Turnhout: Brepols, 2009), p. 307. In this way, their aims overlap with other genres of religious instruction featured in this study, from confessional manuals to guides to right living. On sermons' catechetical aims, see Helen Spencer, English Preaching in the Late Middle Ages (Oxford: Clarendon, 1993), p. 33.

59 Theodore Erbe (ed.), Mirk's Festial: A Collection of Homilies, by Fohannes Mirkus (EETS ES 96, 1905), p. 65.

60 In Luke's Gospel, Jesus narrates Dives and Lazarus to Pharisees described as lovers of money (Luke 16:14), and in the Glossa ordinaria, marginal glosses begin 'Contra derisores auaros'. See Karlfried Froehlich and Margaret T. Gibson (eds), Biblia Latina Cum Glossa Ordinaria: Facsimile Reprint of the Editio Princeps Adolph Rusch of Strassburg 1480/81 (Turnhout: Brepols, 1992), 4:198. 